\title{
Genetic Haemoglobin Disorders in Pakistan
}

\author{
Suhaib Ahmed* \\ Haematology, Riphah International University, Islamabad, Pakistan. \\ doi.org/10.21089/njhs.23.0095
}

\section{INTRODUCTION}

Genetic haemoglobin disorders are broadly divided into thalassaemia syndromes and abnormal haemoglobins. Thalassaemias are a heterogeneous group of inherited disorders of haemoglobin synthesis in which one or more globin chains are either not produced at all $\left(\beta^{\circ}\right)$ or are produced at a reduced rate $\left(\beta^{+}\right)$. These are classified according to the type of globin chain(s) affected. The abnormal haemoglobins are produced in normal amount but are structurally abnormal and therefore lack the usual qualities of haemoglobin. Some abnormal haemoglobins like $\mathrm{Hb}-\mathrm{E}$, in addition to being structurally abnormal are produced in reduced amount [1].

\section{HISTORICAL BACKGROUND}

Thalassaemia was reported from the Indian subcontinent as early as 1938 [1]. The first description of thalassaemia in Pakistan was given by Raheemtoola in 1960 [2]. In 1968 Stern and colleagues were the first to report $4 \%$ carrier rate of $\beta$ thalassaemia amongst Pathans [3]. The prevalence of thalassaemia in Pakistan remained under reported due to the very limited diagnostic facilities [4]. The era of seventies and the eighties saw a fairly good number of studies on the epidemiology of genetic haemoglobin disorders in Pakistan.

In the early eighties a couple of non-governmental organizations (NGO) started blood transfusion services for the children with thalassaemia with an ever increasing number of patients coming to these centres, it became obvious that thalassaemia would soon be recognized as a significant health problem in Pakistan.

The first prenatal diagnosis of thalassaemia was done in May 1994 [5]. The first comprehensive description of molecular pathology of $\beta$-thalassaemia in the major ethnic groups in Pakistan was reported in 1996 [6]. The molecular pathology of $\alpha-$ thalassaemia was reported in 2003 [7].

The bone marrow transplant for thalassaemia was started in 2000 initially at Karachi, followed by a centre at Rawalpindi [8]. In 2003 over three dozen NGOs involved in the management of thalassaemics got together under the umbrella of Thalassaemia Federation of Pakistan (TFP) with a view to adopt uniform management protocol for thalassaemics all over Pakistan.

\section{EPIDEMIOLOGY}

Genetic haemoglobin disorders are the most common single gene disorders in the world. It is estimated that about 250 million people ( $4 \%$ of the world population) carry a gene for thalassaemia or abnormal haemoglobin. $\alpha^{+}$-thalassaemia is the commonest globin mutation. Each year about 240,000 infants are born with a major haemoglobin disorder. Globally, sickle cell disease accounts for nearly $78 \%$ of the affected births, $\beta$ thalassaemia major or $\mathrm{Hb}-\mathrm{E} / \beta$-thalassaemia accounts for about $20 \%$, and $1.6 \%$ is accounted for by $\mathrm{Hb}-\mathrm{S} / \beta$-thalassaemia [9]. The disease has a high prevalence in a broad belt extending from the Mediterranean to the Middle East, Indian subcontinent and South East Asia. The distribution of thalassaemia and other major abnormal haemoglobins coincides with that caused by Plasmodium falciparum malaria. It is thought that the heterozygotes are resistant to malaria and the selective advantage this provides compensates for the continual loss through the death of the homozygotes [10].

The overall carrier rate of $\beta$-thalassaemia in Pakistan is around $5 \%$. However, it tends to vary between the ethnic groups. Balochs have the highest prevalence (8\%) [11-12]. Single gene deletion $\alpha$-thalassaemia $\left(-\alpha^{3.7} \alpha / \alpha \alpha\right)$ is reported in $8.3 \%$ and two gene deletion $\left(-\alpha^{3.7} \alpha /-\alpha^{3.7} \alpha\right)$ in $2.0 \%$ of Pakistanis [7]. Hb$\mathrm{D}$ is mostly confined to Punjab where it is seen in about $1 \%$ of the people [13]. Hb-E is mostly seen in the immigrant population from Bihar and $\mathrm{Hb}-\mathrm{S}$ in the Baloch and Pathan populations.

Based on the $5 \%$ carrier rate of $\beta$-thalassaemia it is estimated that each year approximately 5000 new births of $\beta$ thalassaemia major take place in Pakistan. It is also estimated that there wil be over 50,000 children suffering from thalassaemia major in the coming years in Pakistan [11].

\section{DISTRIBUTION OF THALASSAEMIA GENES}

In Pakistan, $60-90 \%$ of the marriages take place between close relatives or biradri/tribe members $[11,14]$. Due to the longstanding tradition of consanguineous marriages, the genes for 
recessive disorders like thalassaemia are expected to be trapped within the extended family. A study on screening in several families with index patients of genetic haemoglobin disorders in Pakistan showed $\sim 30 \%$ carriers as compared to the $5 \%$ reported in the general population [15]. The study also showed that the families who do not have any history of thalassaemia are almost free from thlassaemia. This study provides strong evidence to suggest that in the populations with high prevalence of consanguineous marriages, the abnormal genes for recessive disorders like thalassaemia may have a highly clustered distribution. It may well be possible that thalassaemia is confined to only a small proportion of the families in Pakistan $(\sim 10 \%)$.

\section{MOLECULAR PATHOLOGY}

\section{$\alpha$-thalassaemia}

Most of the $\alpha$-thalassaemias are caused by the $-\alpha^{3.7}$ deletion whereas the $-\alpha^{4.2}$ deletion is rare. Triplicated $\alpha$-gene ($\left.\alpha^{3.7} \alpha \alpha \alpha / \alpha \alpha\right)$ is reported in about $1 \%$ of the Pakistanis $[7,11]$.

\section{$\beta$-thalassaemia}

In contrast to $\alpha$-thalassaemia majority of the $\beta$-thalassaemias are caused by point mutations affecting the gene expression or regulation. There are two types of $\beta$-thalassaemia, one with some residual $\beta$-globin synthesis $\left(\beta^{+}\right.$-thalassaemia) and the second with no $\beta$-globin synthesis ( $\beta^{\mathrm{o}}$-thalassaemia).

Over 200 different mutations have been identified to cause $\beta$ thalassaemia. These mutations affect the gene expression by a variety of mechanisms [16]. Mutations in the promoter or termination region of the $\beta$-globin gene are usually mild in nature $\left(\beta^{+}\right)$, for example Cap+1 (A-C) is a common $\beta^{+}$mutation in Pakistan. Point mutations in the coding region of the gene (exons) may shift the reading frame (genetic code) forward or backward resulting in creation of new stop signal (TAA) with premature termination of transcription. Fr 8-9 $(+\mathrm{G})$ and Fr 4142 (-TTCT) are common frame shift mutations that cause $\beta^{\circ}$ thalassaemia in Pakistan. Mutations close to the exon-intron junctions create alternate splice sites. This causes abnormal and ineffective splicing of RNA. IVSI-5 (G-C) and IVSI-1 (G-T) are common examples of the splice junction mutations in Pakistan. The Hb-E mutation, in addition to producing structurally abnormal haemoglobin, also creates an alternate splice site in the codon 26. Large deletions are unusual to cause $\beta$ thalassaemia. The best known example is of the 619 bp deletion involving the terminal portion of the gene. This mutation is fairly common in the southern region of Pakistan [6, 17-21].

Rarely, mutations in the $3^{\text {rd }}$ exon of the $\beta$-gene are seen to cause dominant form of $\beta$-thalassaemia in which heterozygotes also become symptomatic. Occasionally, patients with typical $\beta$-thalassaemia may be seen without any detectable mutation in the $\beta$-globin gene or its immediate flanking regions.
It has been shown that thalassaemia phenotype may be caused by mutation in a gene located elsewhere in the genome, which is important in $\beta$-globin gene expression [1].

The spectrum of $\beta$-thalassaemia mutations varies widely in different world populations and each ethnic population has its own set of common and uncommon mutations.

\section{Common $\beta$-thalassaemia Mutations}

The five most common $\beta$-thalassaemia mutations include IVSI5 (G-C), Fr 8-9 (+G), Fr 41-42 (-TTCT), IVSI-1 (G-T) and Del 619 . Together these mutations account for $81.1 \%$ of the total (Table 1). There are significant differences in the frequency of several mutations between the major ethnic groups in Pakistan $[6,17-21]$. For example IVSI-5 is seen in over $75 \%$ of thalassaemics from the Baloch population whereas, it is seen in just $13 \%$ of the Pathan thalassaemia patients. Fr 8-9 is more common in the northern region of Pakistan whereas Del 619 is more frequent in the south. Some $\beta$-thalassaemia mutations are seen at an unexpectedly high frequency in some biradris/tribes. For example IVSI-1 (G-T) mutation is seen in about $25 \%$ patients of thalassaemia from the Sheikh biradri as compared to just $5 \%$ in the rest of the population [11]. This appears to be due to the founder effect.

\section{Uncommon $\beta$-thalassaemia Mutations}

Six uncommon $\beta$-thalassaemia mutations make about $15 \%$ of the total (Table 1). These include Cd 15 (G-A), Cd 30 (G-C), Cd 5 (-CT), Fr 16 (-C), Cap+1 (A-C), and Hb-E. The frequency of uncommon mutations also varies between the ethnic groups $[6,17-21]$.

Table 1. $\beta$-thalassaemia mutations in Pakistan [6].

\begin{tabular}{|c|c|c|c|}
\hline \multicolumn{2}{|c|}{ Common Mutations } & \multicolumn{2}{c|}{ Uncommon Mutations } \\
\hline IVSI-5 (G-C) & $457(36.9 \%)$ & Cd $15(\mathrm{G}-\mathrm{A})$ & $51(4.1 \%)$ \\
\hline Fr 8-9 (+G) & $317(25.6 \%)$ & $\mathrm{Cd} 30(\mathrm{G}-\mathrm{C})$ & $43(3.5 \%)$ \\
\hline Del 619 & $85(6.9 \%)$ & $\mathrm{Cd} 5(-\mathrm{CT})$ & $31(2.5 \%)$ \\
\hline Fr 41-42 (-TTCT) & $82(6.6 \%)$ & Fr 16 (-C) & $29(2.3 \%)$ \\
\hline IVSI-1 (G-T) & $65(5.2 \%)$ & Cap +1 (A-C) & $20(1.6 \%)$ \\
\hline & & Hb-E & $13(1.1 \%)$ \\
\hline & & Others & $47(3.8 \%)$ \\
\hline
\end{tabular}

\section{Rare Mutations}

A wide variety of rare $\beta$-thalassaemia mutations account for about $4 \%$ of the total alleles. Cd 30 (G-A), IVSII-I (G-A), IVSI-1 (G-A) and Cd 37 (G-A) are the most frequent rare mutations $[6,21]$. 
A small fraction of the thalassaemics may carry mutations that are not detectable in the $\beta$-globin gene itself. These are usually suspected when the child has transfusion dependent thalassaemia and its mutation analysis by genomic sequencing shows only one $\beta$-thalassaemia allele.

\section{$\beta$-thalassaemia Trait}

Over $90 \%$ of $\beta$-thalassaemia carriers in Pakistan have typical features i.e haemoglobin in the low normal range, raised TRBC, low MCV and MCH. Hb-A2 levels typically range between $3.5-7.0 \%$ as compared to the normal of $2.5-3.4 \%$. HbA2 levels between 3.0 and $3.4 \%$ are considered borderline and may result from faulty technique, coexisting iron deficiency or $\alpha$-thalassaemia [11].

$\beta^{+}$-thalassaemia trait is uncommon in Pakistan. Most patients of $\beta^{+}$thalassaemia are due to Cap+1 (A-C) mutation [22]. The latter is seen in about $2.5 \%$ of individuals with $\beta$ thalassaemia trait [6]. They have almost normal haematological parameters including $\mathrm{Hb}-\mathrm{A}_{2}$ level except that their Mean Corpuscular Hemoglobin (MCH) is around 26 pg. Because of the silent nature their carrier status is usually discovered when they marry a person with typical thalassaemia trait and give birth to a child with thalassaemia major. The confirmation of Cap +1 mutation is only possible by PCR.

Since iron deficiency is very common in Pakistan it is also common to see it co-existing with $\beta$-thalassaemia trait [23]. Such individuals are more anaemic and have low serum ferritin but their $\mathrm{Hb}-\mathrm{A}_{2}$ levels are usually high. Occasional patients with $\beta$-thalassaemia trait and co-existing iron deficiency may have normal $\mathrm{Hb}-\mathrm{A}_{2}$ levels. In such patients $\mathrm{Hb}-$ electrophoresis may be repeated after correction of iron deficiency.

\section{$\beta$-thalassaemia Major}

The blood picture of typical $\beta$-thalassaemia major is characterized by moderate to severe hypochromic, microcytic anaemia, marked aniso-poikilocytosis and numerous nucleated red blood cells. The white blood cell count usually appears elevated due to the presence of numerous nucleated red blood cells that are counted as white blood cells by the electronic counters. The diagnosis is confirmed by markedly elevated levels of fetal haemoglobin ( $\mathrm{Hb}-\mathrm{F})$ that ranges from $30 \%$ to over $95 \%$ [24]. In an un-transfused patient, presence of $\mathrm{Hb}-\mathrm{A}$ indicates $\beta+-$ thalassaemia whereas its absence indicates $\beta^{\circ}$-thalassaemia.

Most of the diagnosed patients of thalassaemia major are registered with thalassaemia treatment centres run by the NGOs. Majority of these patients are registered at more than one NGO therefore, their exact numbers are not known. The standard of treatment is generally not up to the mark. Thalassaemia Federation of Pakistan has recently issued comprehensive guidelines for the management of thalassaemia for the member organizations. But in the absence of audit, the compliance to the management protocol is poor. The outcome of treatment at most of the centres is not satisfactory. Mean pre-transfusion haemoglobin of the patients receiving regular blood transfusions was 6.5 $\mathrm{g} / \mathrm{dl}$ with values ranging between $3.0-9.5 \mathrm{~g} / \mathrm{dl}$ [25]. This is primarily due to the poorly developed transfusion services, inadequate voluntary blood donations and the lack of awareness amongst the treating physicians and the affected parents about the benefits of hyper-transfusion regimen. The status of iron chelation is not different. Most of the screening of blood for hepatitis B and C is done with rapid devices. Unfortunately, $60 \%$ of the multiple transfused thalassaemics are positive for Hepatitis-C [26]. Fortunately, the transmission of HIV is not a significant problem [27]. Hydroxyurea is also being successfully used to reduce the transfusion dependency in thalassaemia intermedia and selected patients of thalassaemia major [28, 29].

Stem cell transplantation for thalassaemia is available in Pakistan since late nineties. The facility is available at five centres and each year over 50 transplants are done for thalassaemia. The donors in most transplants are their siblings. Recently haploidentical transplants have also been done. The long term survival in ex-thalassaemics is around $72 \%$ [8].

\section{$\delta \beta$-thalassaemia}

It is an uncommon entity in Pakistan but is more frequent in the Bohra community [30]. The $\delta \beta$-thalassaemia heterozygotes have normal haemoglobin with marginally low MCV and $\mathrm{MCH}$. They have normal or low $\mathrm{Hb}-\mathrm{A}_{2}$ but their $\mathrm{Hb}-\mathrm{F}$ ranges between $10-15 \%$. Homozygotes of $\delta \beta$-thalassaemia have the phenotype of mild thalassaemia intermedia with $100 \% \mathrm{Hb}-\mathrm{F}$. Almost all of the Pakistani patients have unique Inv/Del ${ }^{\mathrm{G}} \gamma\left({ }^{\mathrm{A}} \gamma \delta \beta\right)^{\mathrm{o}}$ mutation that is strongly linked to the Xmn-I polymorphism [31]. The identification of $\delta \beta$ thalassaemia is important because its co-inheritance with typical $\beta$-thalassaemia trait can result in transfusion dependent thalassaemia major.

\section{$\beta$-thalassaemia Intermedia}

$\beta$-thalassaemia intermedia is a clinical entity that lies in severity between thalassaemia trait and typical thalassaemia major. It covers a broad spectrum of heterogeneous disorders. At one extreme there may be patients who never receive blood transfusion while at the other extreme patients whose disease is slightly less severe than typical thalassaemia major. At the molecular level, several factors may be responsible for the mild phenotype of thalassaemia that may exist in each patient either alone or in combinations.

$\beta$-thalassaemia intermedia comprises approximately $7 \%$ of the clinically significant thalassaemias in Pakistan. At the molecular level approximately $1 / 3^{\text {rd }}$ of the patients each are caused by mild mutations (mostly Cap +1 and $\mathrm{Hb}-\mathrm{E}$ ), co-inheritance of $\alpha$ thalassaemia and Xmn-I polymorphism (+/+ genotype) [11].

\section{Hb-S Disorders}

$\mathrm{Hb}-\mathrm{S}$ disorders are mostly confined to the Baloch and Pathan populations [11]. Since $\beta$-thalassaemia is common in Paki- 
stan it is not uncommon to find it in combination with $\mathrm{Hb}-\mathrm{S}$. The patients may present with combination of transfusion dependency (thalassaemia) and occasional painful sickling crisis $(\mathrm{Hb}-\mathrm{S})$. A peculiar feature of $\mathrm{Hb}-\mathrm{S}$ in Pakistan is its strong linkage with the Xmn-I polymorphism. These patients have the ability to produce greater amount of $\mathrm{Hb}-\mathrm{F}$ than the typical African with $\mathrm{Hb}-\mathrm{S}$. Therefore, $\mathrm{Hb}-\mathrm{S}$ disorders in $\mathrm{Pa}-$ kistan tend to have a mild phenotype.

\section{Hb-E Disorders}

Most of the patients with $\mathrm{Hb}-\mathrm{E}$ in Pakistan are amongst the immigrants from Bihar. A few isolated pockets are also seen in Azad Kashmir and around Abbottabad [11]. Hb-E in Pakistan exists with and without Xmn-I polymorphism. Those who have Xmn-I polymorphism have a milder disease and vice versa. This accounts for variation in the phenotype amongst different patients in spite of having the same mutation. Variation in the phenotype may also be caused by coinheritance of $\alpha$-thalassaemia in some patients.

\section{Hb-D Disorders}

$\mathrm{Hb}-\mathrm{D}$ is an asymptomatic disorder in the heterozygotes as well as homozygotes. The blood picture is also normal. It is mostly seen in approximately $1 \%$ of the Punjabis [13]. Hb-D exists as two different genotypes in Pakistan. Hb-D Punjab (Cd 121 Glu-Gln) is more common than Hb-D Iran (Cd 22 Glu-Gln). Both of the genotypes are clinically silent and have the same electrophoretic mobility but their genotypes can be differentiated by PCR [32].

\section{Hb-C Disorders}

$\mathrm{Hb}-\mathrm{C}$ is common in West Africa, but is extremely rare in the Pakistani population [11].

\section{Prevention of Thalassaemia in Pakistan}

Carrier screening for thalassaemia is mostly voluntary. Screening facilities are available only at selected labs in the large cities [33]. Prenatal diagnosis is available since 1994 $[5,34-36]$. The facility is available at six centres. Each year over 1500 tests are done. The error rate in diagnosis is reported at around $0.5 \%$ [37]. There is a religious consensus on termination of pregnancy for severe genetic disorders like thalassaemia and over $90 \%$ of the couples requesting prenatal diagnosis opt for termination of pregnancy when required [34]. Punjab Thalassaemia Prevention Programme (PTPP) is the largest government sponsored programme that offers free of cost carrier screening and prenatal diagnosis. The PTPP is based on the targeted screening in the index families of thalassaemia [15].

\section{CONCLUSION}

Genetic haemoglobin disorders are the commonest single gene disorders in Pakistan. Approximately 5\% of the population carries the gene for thalassaemia. It is estimated that each year 5000 children are born with thalassaemia major.
Other significant genetic haemoglobin disorders include $\mathrm{Hb}$ $\mathrm{S}, \mathrm{Hb}-\mathrm{E}$ and $\delta \beta$-thalassaemia. The treatment facilities are inadequate that results in high mortality of children with thalassaemia major. Stem cell transplantation is also available since late nineties. Carrier screening is mostly voluntary. Prenatal diagnosis is also available since early nineties but its use remains limited.

\section{CONFLICT OF INTEREST}

Declared none.

\section{ACKNOWLEDGEMENT}

Declared none.

\section{REFERENCES}

[1] Weatherall DJ, Clegg JB. The thalassaemia syndromes. 4th ed London: Blackwell Science; 2001. 827p

[2] Raheemtoola RJ. Cooley's anaemia in Pakistani children. Medicus, 1960; 20: 101 .

[3] Stern MA, Kynoch PA, Lehmann H. $\beta$-thalassaemia, glucose-6phosphate-dehydrogenase deficiency, and haemoglobin D-Punjab in pathans. Lancet, 1968; 291(7555): 1284-5. DOI: 10.1016/s01406736(68)92296-4

[4] Saleem M. Haemoglobinopathies. Pak. Armed Forces Med. J., 1974; 25: 9-12.

[5] Ahmed S, Saleem M, Rashid Y. The first prenatal diagnosis of thalassaemia in Pakistan: a case report. Pak. J. Pathol., 1994; 5: 6971.

[6] Ahmed S, Petrou M, Saleem M. Molecular genetics of $\beta$ thalassaemia in Pakistan: a basis for prenatal diagnosis. $\mathrm{Br}$. $\mathrm{J}$. Haematol., 1996; 94(3): 476-81.

[7] Khan SN, Hasan F, Sollaino C, Perseu L, Riazuddin S. Molecular characterization of $\alpha$-thalassemia in Pakistan. Hemoglobin. 2003; 27(3): 161-6

[8] Shamsi TS, Hashmi K, Adil S, Ahmad P, Irfan M, Raza S, et al. The stem cell transplant program in Pakistan-the first decade. Bone Marrow Transplant., 2008; 42: 114-117. DOI: 10.1038/bmt.2008.137

[9] Modell B, Darlison M. Global epidemiology of haemoglobin disorders and derived service indicators. Bull. World Health Org., 2008; 86(6): 480-7. DOI: 10.2471/blt.06.036673

[10] Modell B and Berdoukas V. The clinical approach to thalassaemia London: Grune \& Stratton; 1984. 1-464.

[11] Ahmed S. An approach for the prevention of thalassaemia in Pakistan. PhD Thesis. England: University of London; 1998. http://discovery.ucl.ac.uk/id/eprint/1317916

[12] Khattak MF and Saleem M. Prevalence of heterozygous $\beta$ thalassaemia in the Northern areas of Pakistan. J. Pak. Med. Assoc. 1992; 42(2): 32-34.

[13] Khattak MF and Saleem M. Structural haemoglobin variants in adult healthy population of Northern Pakistan. Pak. J. Pathol., 1992; 3: 85-8.

[14] Bittles AH. The role and significance of consanguinity as a demographic variable. Pop. Dev. Rev., 1994; 20(3): 561-84. DOI: $10.2307 / 2137601$

[15] Ahmed S, Saleem M, Modell B, Petrou M. Screening extended families for genetic haemoglobin disorders in Pakistan. N. Engl. J. Med., 2002; 347: 1162-68. DOI: 10.1056/NEJMsa013234 
[16] Huisman TH, Carver MF. The $\beta$ - and $\delta$-thalassaemia repository (Ninth edition; Part I). Haemoglobin, 1998; 2: 169-95.

[17] Khateeb B, Moatter T, Shaghil AM, Haroon S, Kakepoto GN. Genetic diversity of $\beta$-thalassemia mutations in Pakistani population. J. Pak. Med. Assoc., 2000; 50(9): 293-6.

[18] Usman M, Moinuddin M, Ghani R, Usman S. Screening of five common $\beta$-thalassemia mutations in the Pakistani population: a basis for prenatal diagnosis. Sultan Qaboos Univ. Med. J., 2009; 9(3): $305-10$

[19] Ansari SH, Shamsi TS, Ashraf M, Farzana T, Bohray M, Perveen $\mathrm{K}$, et al. Molecular epidemiology of $\beta$-thalassemia in Pakistan: far reaching implications. Indian J. Hum. Genet., 2012; 18(2): 193-7. DOI: 10.4103/0971-6866.100762

[20] Khattak SA, Ahmed S, Anwar J, Ali N, Shaikh KH. Prevalence of various mutations in $\beta$-thalassaemia and its association with haematological parameters. J. Pak. Med. Assoc., 2012; 62(1): 40-3.

[21] Yasmeen H, Toma S, Killeen N, Hasnain S, Foroni L. The molecular characterization of $\beta$-globin gene in thalassemia patients reveals rare and a novel mutations in Pakistani population. Eur. $J$. Med. Genet., 2016; 59(8): 355-62.

DOI: 10.1016/j.ejmg.2016.05.016

[22] Karim MU, Moinuddin M, Babar SU. Cap +1 mutation; an unsuspected cause of $\beta$-thalassaemia transmission in Pakistan. Turk. J. Haematol., 2009; 26(4): 167-70.

[23] Qureshi TZ, Anwar M, Ahmed S, Khan DA, Saleem M. Serum ferritin levels in carriers of $\beta$-thalassaemia trait. Acta Haematol., 1995; 94(1): 7-9. DOI: 10.1159/000203963

[24] Ahmed S, Rehman ZU, Karamat KA. Diagnosis of $\beta$-thalassaemia major in previously transfused patients. J. Coll. Physicians Surg. Pak., 2003; 13: 19-21.

[25] Saleem M, An overview of thalassaemia in Pakistan. Proceedings of the PMA International Seminar on thalassaemia, Lahore, (1996)

[26] Bhatti FA, Amin M, Saleem M. Prevalence of antibody to hepatitis $\mathrm{C}$ virus in Pakistani thalassaemics by particle agglutination test utilizing C-200 and C22-3 viral antigen coated particles. J. Pak. Med. Assoc., 1995; 45: 269-71.

[27] Tariq WZ, Hussain SZ. Potential of future spread of HIV/AIDS in Pakistan. Proceedings of COMSTECH symposium on policy briefing on AIDS: prevention and control. Islamabad: 1995. 11130 .
[28] Ansari SH, Shamsi TS, Khan MT, Munzir S, Erum S, Perveen K, et al. Genetic modifiers of $\beta$-thalassaemia associated with management without blood transfusion: ten years' experience. Blood, 2013; 122(21): 4849.

[29] Ansari SH, Lassi ZS, Ali SM, Adil SO, Shamsi TS. Hydroxyurea for ß-thalassaemia major. Cochrane Database Syst. Rev., 2016, (1) DOI: $10.1002 / 14651858 . C D 012064$

[30] Ahmed S and Anwar M. Haematological and genetic features of $\delta \beta$-thalassaemia in Pakistan. J. Coll. Physicians Surg. Pak., 2006; 16(1): 19-22

[31] Ahmed S and Anwar M. Xmn-I G $\gamma$-polymorphism in six unrelated Pakistani families with Inv/Del $\mathrm{G} \gamma(\mathrm{A} \gamma \delta \beta)^{\circ} \delta \beta$-thalassaemia. Am. J. Haematol., 2005; 80(4): 303-5. DOI: 10.1002/ajh.20376

[32] Zakerinia M, Ayatollahi M, Rastegar M, Amanat Mh, Askarinejad AR, Amirghofran S, et al. Hemoglobin D (Hb D Punjab/ Los Angeles and $\mathrm{Hb} \mathrm{D}$ Iran) and co-inheritance with alpha- and betathalassemia in southern Iran. Iran Red Crescent Med. J., 2011; 13(7): 493-8.

[33] Asif N, Hassan K. Prevention of $\beta$-thalassemia in Pakistan. JIMDC. 2014; 3(2): 46-47.

[34] Ahmed S, Saleem M, Petrou M, Sultana N, Raashid Y, Waqar M, et al. Prenatal diagnosis of $\beta$-thalassaemia in Pakistan: experience in a muslim country. Prenat. Diagn., 2000; 20: 378-83. DOI: 10.1002/(SICI)1097-0223(200005)20:5<378::AID$\mathrm{PD} 815>3.0 . \mathrm{CO} ; 2-7$

[35] Mahmood BS, Sabih D, Rahim MK, Azhar A, Tariq M, Sajid HM, et al. $\beta$ - thalassemia in Pakistan: a pilot programme on prenatal diagnosis in Multan. J. Paediatr. Hematol. Oncol., 2012; 34: 90-92. DOI: 10.1097/MPH.0b013e31823752f3

[36] Ansari SH, Shamsi TS, Ahmed FN, Perveen K, Ahmed G. Effectiveness and feasibility of transabdominal chorionic villous sampling procedure for prenatal diagnosis of $\beta$-thalassaemia in a muslim majority community of Pakistan. Pak. J. Med. Sci., 2012; 28(4): 575-9.

[37] Ahmed S. Prenatal diagnosis of $\beta$-thalassaemia: twelve years experience at a single laboratory in Pakistan. Prenat. Diagn., 27: 1224-1227. DOI: $10.1002 /$ pd. 1878 